\title{
Legal Education for the Pro Se Litigant: A Step Towards a Meaningful Right To Be Heard
}

\author{
Helen B. Kim
}

Civil litigants have the right to be heard in federal $^{\mathbf{1}}$ and state ${ }^{\mathbf{2}}$ courts. The right to be heard has little value, however, to those who lack the knowledge to exercise their right in a meaningful or skillful way. The notion of a meaningful right to be heard has been linked to access to counsel. ${ }^{3}$ In Powell v. Alabama, the Supreme Court noted, "[t]he right to be heard would be, in many cases, of little avail if it did not comprehend the right to be heard by counsel. Even the intelligent and educated layman has small and sometimes no skill in the science of law." Several commen-

1. See 28 U.S.C. $\$ 1654$ (1982) ("parties may plead and conduct their own cases personally or by counsel").

2. In some states, the right to be heard is defined explicitly in terms of a right to prosecute or defend in person. See, e.g., A I.A. Consr. art. I, $\S 10$ ("no person shall be barred from prosecuting or defending before any tribunal in this state, by himself or counsel, any civil cause to which he is a party"); Ga. Consr. art I, para. XII; Mich. Const. art. I, \$13; MIss. Const. art. 3, § 25; UtaH ConsI", art I, $\$ 11$; WIs. Consr. art I, $\S 21(2)$. In other states, the right to prosecute or defend in person arises by statute. See, e.g., Fl.A. STAr. ANN. $\$ 454.18$ (Harrison 1978); 42 Pa. Cons. Stat. ANN. \$2501(a) (Purdon 1981); Wash. Rrv. CoDF ANN. $\$ 2.48 .190$ (1961). In most states, the constitutional right to be heard is encompassed by the more general right to redress of injuries. See, e.g., ARK. Constr. art. II, § 13; Conn. Consr. art. I, § 10; Dri. Const. art. I, § 9; Fla. Const. art. I, § 21; Inaho Const. art. I, § 18; Ir.l. Const. art. I, § 12; IND. Const. art. I, § 12; KaN. Consr. Bill of Rights, $\$ 18$; KY. Const. $\S 14$; LA. Consr. art. I, $\$ 22$; ME. Const. art. I, $\S 19$; MD. Const: Declaration of Rights, art. 19; Mass. Const. art. XI; MINN. Const. art. I, § 8; Mo. Const. art. I, § 14; Mont. Const: art. I, $\$ 16 ;$ N.H. Consr. Bill of Rights, art. 14; N.C. Const. art. I, § 18; Ohio Consr. art. I, § 16; OKL.A. Consr. art. II, § 6; OR. Const. art. I, § 10; R.I. Consi. art. I, \$ 5; S.C. Const. art. I, § 9; S.D. Consr. art. VI, § 20; TrnN. Consr. art. I, § 17; Tr.X. Const. art. I, \$ 13; Vr. Const. ch. I, art. 4; W. VA. Const. art. III, § 17; Wyo. Consr. art. I, $\$ 8$.

3. See, e.g., Freedman, Lawyer-Client Confidences and the Constitution (Book Review), 90 YALE L.J. 1486, 1494 (1981):

[O]ur social institutions are so complex that, without the assistance of an expert adviser, a lay person cannot exercise the personal autonomy to which he or she is morally and constitutionally entitled. "Without such an adviser... the law would impose constraints on the lay citizen (unequally at that) which it is not entitled to impose explicitly."

Id. at 1494 (quoting Fried, The Lawyer as Friend: The Moral Foundations of the Lawyer-Client Relation, 85 YAI.F. L.J. 1060, 1073 (1976)); see also Cheatham, The Lawyer's Role and Surroundings, 25 Rocky MiN. L. Rr.v. 405 (1953):

Law is not self-applying; men must apply and utilize it in concrete cases. But the ordinary man is incapable. He cannot know the principles of law or the rules guiding the machinery of law administration; he does not know how to formulate his desires with precision and to put them into writing; he is ineffective in the presentation of his claims.

Id. at 405 .

4. 287 U.S. 45, 68-69 (1932) (quoted in Gideon v. Wainwright, 372 U.S. 335, 344-45 (1963)). 
tators have argued that the logic of Powell applies no less to civil litigants, and that the due process clause mandates a right to counsel for civil litigants, as well. ${ }^{\circ}$

This Note, however, argues that provision of counsel need not be the only solution to the pro se litigant's dilemma: Lawyers and paralegals can assist the pro se litigant by educating her about her legal situation. Experience has shown that providing general legal information to pro se litigants can significantly increase their chances of success both in court and in settlement negotiations. ${ }^{6}$

Civil litigants who are unable to hire counsel cannot rely on obtaining counsel from other sources to ensure a meaningful right to be heard. In only limited circumstances are civil litigants constitutionally entitled to court-appointed counsel. ${ }^{7}$ Legal services programs, ${ }^{8}$ the primary source of individual attorney representation for the indigent, ${ }^{8}$ are turning away many eligible persons ${ }^{10}$ because they cannot meet the demand for their services. ${ }^{11}$ Furthermore, other sources of legal assistance have been unable

5. Since Gideon, in which the Supreme Court relied heavily upon Powell in declaring that an indigent criminal defendant's right to counsel is a fundamental one, several commentators have argued for the application of the Court's reasoning in Powell to indigent civil litigants. See Note, The Right to Counsel in Civil Litigation, 66 Col.um. L. Rev. 1322 (1966); Note, The Emerging Right of Legal Assistance for the Indigent in Civil Proceedings, 9 U. MicH. J.L. REF. 554 (1976); Note, The Indigent's Right to Counsel in Civil Cases, 76 YAL.E L.J. 545 (1967).

6. According to New Haven Legal Assistance Association, Inc. (NHLAA), tenants who received summary eviction notices and then received "brief service" at NHLAA-one-half hour informational consultations with paralegals-fared markedly better in pro se capacity than tenants who did not. The NHLAA study showed that the informed tenants obtained significantly longer time in their premises than their uninformed counterparts. See D. Pollack, Advice Only/Brief Service Effectiveness Study for New Haven Legal Assistance $\Lambda$ ss'n, Inc. 2-3 (Aug. 26, 1986) (on file with author) (brief service recipients received 77 days, as opposed to 44 days for other pro se tenants). But the study also showed that brief service recipients often obtained longer stays of execution at the price of paying more arrearages to the plaintiff/landlord. Id.

7. See infra notes $34-40$ and accompanying text.

8. As of June 18,1985, 324 independent legal service programs received financial support from the Legal Services Corporation (LSC) to provide legal assistance in civil matters to the indigent. Legai. Servichs Corporation, 1985 Fiei.d Program Data 1, 16 (1985) (hereinafter 1985 Field Program Data]. The Legal Services Corporation is an autonomous, non-profit organization created and funded by Congress to provide "financial support for legal assistance in noncriminal proceedings or matters to persons financially unable to afford legal assistance." Legal Services Corporation $\Lambda$ ct of 1974, Pub. L. No. 93-355, $\$ 1003,88$ Stat. 378 (codified as amended at 42 U.S.C. $\$ 2996$ (1982)). While a few legal service organizations do not receive funding from LSC, LSC "provides funds to almost all legal aid programs in the country." Legal Services Corporation Reauthorization: Hearings on H.R. 2506 and H.R. 3480 Before the Subcomm. on Courts, Civil Liberties, and the Administration of Justice of the House Comm. on the Judiciary, 97th Cong., Ist Sess. 682 (1981).

9. For a historical survey of civil legal services for the poor, see J. Dooley \& A. Houseman, Legal Services History (Nov. 1984) (unpublished manuscript); see also Special Project, The Legal Services Corporation: Past, Present, and Future?, 28 N.Y.L. SCH. L. REv. 593, 593-612 (1983).

10. Eligibility for LSC funding is determined by guidelines promulgated by the LSC under the Legal Services Corporation Act of 1974, Pub. L. No. 93-355, § 1007, 88 Stat. 378 (codified as amended at 42 U.S.C. $\$ 2996$ f (1982)).

11. For example, NHL $\Lambda \Lambda$ served a poverty population of 63,000 in New Haven, handled 3,000 cases through its staff attorneys, reached 10,000 others with self-help information, and referred 6,500 cases to other organizations or private attorneys in 1984. See Pamphlet from New Haven Legal $\Lambda$ ssis- 
to fill the gap. ${ }^{12}$ Finally, non-attorney sources of legal information, such as self-help literature, ${ }^{13}$ even if available, are inherently of limited utility. ${ }^{14}$ Despite these disadvantages, pro se litigants are often held to the same standard of knowledge as licensed attorneys. ${ }^{16}$

This Note proposes that legal services programs consider an alternative to attorney representation: Attorneys or paralegals can educate prospective pro se litigants through classroom instruction in which legal problems common to the community are addressed and explained. ${ }^{16}$ Classroom instruction can help the pro se litigant understand and effectively present her legal position in court. Armed with general knowledge of the relevant substantive and procedural law, as well as standardized legal documents, ${ }^{17}$ the pro se litigant can more successfully present her claims or defenses before a court.

Section I of this Note discusses the judicial hostility that pro se litigants may encounter when exercising their right to be heard, and the unavoidability of appearing pro se due to the limited availability of legal assistance. Section II describes classroom education as a viable means of providing legal information. Section III addresses possible arguments against the delivery of legal information through classes, and, in particular, the applicability of the Model Code of Professional Responsibility ${ }^{18}$ and the Model Rules of Professional Conduct. ${ }^{19}$ Finally, Section IV pro-

tance $\Lambda$ ss'n to Friends of Legal Services (on file with author) [hereinafter New Haven Pamphlet]. On average, three out of every four eligible persons who applied for services were turned away because of insufficient staff. See Letter from Peter B. Cooper, President of Friends of Legal Services for South Central Connecticut (November 1986) (on file with author); see also Arriola \& Wolinsky, Public Interest Practice in Practice: The Law and Reality, 34 Hasrincs L.J. 1207, 1207 \& n.43 (1983).

12. See infra note 52 . Other sources of legal assistance include law firms and private attorneys who agree to provide legal services to clients on a flat-fee or fee-for-service basis; prepaid legal services plans; legal clinics; voucher systems; and pro bono programs. For a description of these modes of

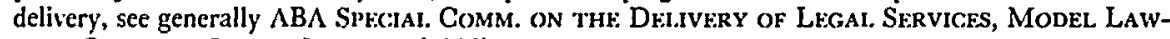
yrRs GuInE To LF(iAI. Srikvicies (1983).

13. See infra note 59.

14. See infra Section I. $\Lambda .3$.

15. See infra notes 20-32 and accompanying text.

16. Although this Note focuses on legal services programs, meaning LSC-funded legal aid programs that assist eligible people, see supra note 10 , private law firms and clinics servicing primarily low-income clients should also consider offering classroom instruction for pro se litigants. Those who are just above the poverty level and are ineligible for legal aid programs present "one of the great unmet legal needs in our society today." $\Lambda B A$, Final. Report of THE. Special. Committee to Survey Lic;al. NFibs 53 (1978).

17. For a discussion of standardized, as opposed to individualized legal services, see Hazard, Pearce \& Stempel, Why Lawyers Should Be Allowed To Advertise: A Market Analysis of Legal Services, 58 N.Y.U. L. Rkv. 1084, 1090-91, 1100-03 (1983); Muris \& McChesney, Advertising and the Price and Quality of Legal Services: The Case for Legal Clinics, 1979 AM. B. Found. Res. J. $179,191-93$.

18. Monki. Conf: of Professional. Rrsponsibiliriy (1981) [hereinafter Monfi. Code].

19. Monfi. Rui.fs of Proffissionat. Conducre (1983) [hereinafter Modit. Rul.es]. The Model Rules were adopted by the House of Delegates of the American Bar Association on August 2, 1983. 
poses standards grounded in tort law that should govern the conduct of lawyers and paralegals who teach pro se litigants.

\section{Exercising the Right To Be Heard}

Our courts are based on an adversarial system that relies upon knowledgeable parties on both sides of the controversy to focus, develop, and present all relevant facts and legal arguments to the court. ${ }^{20}$ The parties are not only assured the opportunity, but also bear the burden ${ }^{21}$ of doing so. Consequently, our adversarial system may work unfairly ${ }^{22}$ for those who are unable either to assert effectively legal rights on their own behalf or to hire a lawyer for that purpose. ${ }^{23}$

For this reason, some courts have granted pro se litigants a degree of special consideration. In Haines v. Kerner, ${ }^{24}$ the Supreme Court held that a pro se litigant's pleadings must be liberally construed. In the spirit of Haines, some courts have sought to protect pro se litigants from forfeiture

20. It is commonly acknowledged that our adversarial system is not a truth-seeking venture, but a means to resolve disputes based only on information presented to the adjudicator. As Judge Marvin E. Frankel has noted, "[T]he contest by its very nature is not one in which the objective of either side, or of both together, is to expose 'the truth, the whole truth, and nothing but the truth.' " $M$. FRankEL, ParTISAN Jusitck: 14 (1980). "The deciders, though commissioned to discover the truth, are passive recipients, not active explorers. They take what they are given. They consider the questions raised by counsel, rarely any others. Issues not joined are not resolved, though they might have led to wiser, fairer dispositions than those reached." Id. at 13. For discussions on adversarial justice, see M. FRANKel, ThE: Skarch for TruTh-AN UMpireal Vifw (1975) [hereinafter M. Frankel, ThE Search for Truth]; S. Landsman, The Adversary Systrm (1984); Dauer \& Leff, The Lawyer as Friend (Correspondence), 86 Yal.E. L.J. 573 (1977); Fried, The Lawyer as Friend: The Moral Foundations of the Lawyer-Client Relation, 85 YAl.E. L.J. 1060 (1976); Simon, The Ideology of Advocacy: Procedural Justice and Professional Eithics, 1978 Wis. L. Rev. 29; White, The Ethics of Arguments: Plato's Gorgias and the Modern Lawyer, 50 U. CHI. L. REv. 849 (1983).

21. In Osborn v. Manning, 685 P.2d 1121, 1124-25 (Wyo. 1984), the Wyoming Supreme Court rejected a pro se plaintiff's assertion that the trial court should have asked questions or suggested that plaintiff produce evidence necessary to supplement or clarify the case; the court found that such conduct would be inconsistent with the impartial position required of all judges.

22. A trial judge may invoke judicial discretion to assist the pro se litigant, and, in fact, it is common practice to do so. Yet, despite good intentions, the judge's assistance may not be sufficient to overcome disadvantages resulting from the lack of counsel. As Judge Frankel has noted:

The fact is that our system does not allow much room for effective or just intervention by the trial judge in the adversary fight about the facts. The judge views the case from a peak of Olympian ignorance. His intrustions will in too many cases result from partial or skewed insights. . . He runs a good chance of pursuing inspirations that better informed counsel have considered, explored, and abandoned after fuller study. He risks at a minimum the supplying of more confusion than guidance by his sporadic intrusions.

M. Frankel., Thy Srarch for Truth, supta note 20, at 22.

23. In the context of cases handled by legal services programs, one commentator observed:

It is almost certain that an individual acting without an attorney could not have prevailed .... Indeed, absent legal advice, either the poor person would not have recognized that a legal issue was presented, or would not have known how to institute litigation or assert a defense. The skills of a lawyer were vital to developing the facts, arguing the law, negotiating settlements or preparing pleadings.

Special Project, supra note 9, at 629.

24. 404 U.S. 519 (1972). 
of important rights when a pro se litigant's actions stem from ignorance of procedural matters. ${ }^{28}$ Other courts, however, have expressed no sympathy for the pro se litigant, even on procedural matters. ${ }^{26}$

The courts appear to agree, however, that it is not necessary to provide pro se litigants with guidance or information concerning relevant substantive law. ${ }^{27}$ In fact, some courts have held the pro se litigant to the same standard of substantive legal knowledge as a licensed member of the bar. ${ }^{28}$ Thus, for those who, because of their financial inability ${ }^{29}$ to hire counsel,

25. See, e.g., Blair v. Maynard, 324 S.E.2d 391 (W.Va. 1984) (declaration of mistrial overturned because pro se litigant's opening remarks constituted excusable mistake). The court said:

We are not proposing that trial judges should become surrogate attorneys for pro se litigants.

The fundamental tenet that the rules or procedures should work to do substantial justice,

however, commands that judges painstakingly strive to insure that no person's cause or defense

is defeated solely by reasons of their unfamiliarity with procedural or evidentiary rules.

Id. at 396 (footnote omitted); see also Traguth v. Zuck, 710 F.2d 90 (2d Cir. 1983) (default judgment set aside where pro se defendant did not know she faced default if she did not answer complaint within 20 days).

26. The court in Homecraft Corp v. Fimbres, 119 Ariz. 299, 301, 580 P.2d 760, 762 (1978) noted: "Experience. . . indicates that all too often litigants who appear in propria persona deliberately attempt to capitalize upon their own ignorance or appearance of ignorance." (quoting Monastcro v. Los Angeles Transit Co., 131 Cal. App. 2d 156, 162, 280 P.2d 187, 192 (1955)). The trial court entered a $\$ 10,000$ execution against pro se defendants' home to satisfy a $\$ 450$ judgment. Thereafter, defendants retained counsel and moved for relief from the judgment. That trial court, noting, "[i]t is obvious that the Defendants Fimbres without the benefit of counsel had no real conception or understanding of the legal processes," 119 Ariz. at 300,580 P.2d at 761, granted defendants' motion for relief and set aside the judgment. The appellate court, however, found that the trial court erred in setting aside the judgment, and refused to compensate for defendants' disadvantages. See also Sunpower Inc. v. Hawley, 296 N.W.2d 532, 533 (S.D. 1980) (pro se party may not capitalize on unfamiliarity with law).

27. See, e.g., Nelson v. Jacobsen, 669 P.2d 1207, 1213 (Utah 1983) ("Reasonable consideration for a layman acling as his own attorney does not require the court to . . translate legal terms, explain legal rules, or otherwise attempt to redress the ongoing consequences of the party's decision to function in a capacity for which he is not trained."); Osborn v. Manning, 685 P.2d 1121 (Wyo. 1984) (rejecting pro se litigant's request for court assistance in determining evidence necessary to establish prima facie case).

28.

When one undertakes to represent himself he . . is held to the same familiarity with required procedures and the same notice of statutes and local rules as would be attributed to a duly qualified member of the bar. . . . As far as the law is concerned, the parties were on an equal footing with regard to legal principles and procedures.

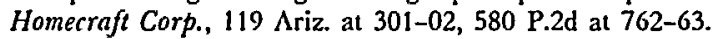

Another court acknowledged that while it has "a duty to be courteous and fair . . . it has no duty to practice law for the pro se litigant." Sunpower, 296 N.W.2d at 533. Plaintiff had sued to recover the amount owed to it for the sale and installation of solar collectors. Pro se defendant failed to answer plaintiff's complaint, but asserted at the hearing on plaintiff's motion for default judgment that he did not pay because the solar collectors were defective. Nonetheless, the court entered a default judgment and denied defendant's motion to set aside the judgment. In justifying its decision, the court remarked that "[a pro se litigant] may not capitalize on his unfamiliarity with law; he is bound by the same rules of evidence and procedure as is required by those who are duly licensed to practice law.' "Id. (quoting Stark v. Stark, 79 S.D. 178, 181, 109 N.W.2d 904, 906 (1961)). Apparently, the court's concept of its duty to be fair did not preclude penalizing the pro se defendant for failure to assert his defense in a formal answer, despite the defendant's oral presentation of his defense.

29. $\Lambda$ person who is financially able to hire an attorney, but whose claim is worth less than the cost of hiring an attorney, is in the same position as the indigent litigant: If she chooses to exercise her right to be heard at all with respect to that claim, she will do so without the benefit of counsel. For 
must exercise their right to be heard without the benefit of counsel-if they are to be heard at all-the consequences of bearing that risk can be harsh. ${ }^{30}$

The cases reflect the obvious tension between a court's desire to protect the ignorant pro se litigant and the need to preserve the integrity of the adversarial system in which the court is the passive adjudicator. The fact that courts have opted to maintain their functional integrity should not be surprising. Courts cannot be expected to assume the awkward position, not to mention the imposition, ${ }^{31}$ of serving as both adjudicator and counsel for the pro se litigant. Such a position would place the court in conflict with the very structure of the adversarial system. ${ }^{32}$

\section{A. Obtaining Legal Assistance to Exercise the Right To Be Heard}

Among the solutions that will relieve courts of this dilemma are the provision of legal counsel and a knowledgeable pro se litigant. ${ }^{33}$ Current methods available for assisting those unable to hire counsel have insufficiently answered their legal needs.

\section{Limited Availability of Court-Appointed Counsel}

In contrast to criminal defendants, civil litigants unable to afford counsel generally cannot turn to the court for appointment of counsel. ${ }^{34}$ While

discussions on the factors influencing a layperson's decision to hire counsel or litigate, see R. POSNER, Economic: Anal.ysis of Law $\$ \$ 21.8-21.9$ (3d ed. 1986); Project, An Assessment of Alternative Strategies for Increasing Access to Legal Services, 90 Y.AL.E. L.J. 122, 131-38 (1980) (theory of factors influencing layperson's decision to consult attorney); Note, On Letting the Laity Litigate: The Petition Clause and Unauthorized Practice Rules, 132 U. PA. L. Rrv. 1515, 1541-42 (1984) (analysis of factors influencing layperson's decision to litigate, with or without counsel).

30. See infra Section II.

31. See Special Project, supra note 9, at 668-69 and citations therein (discussing burdens that pro se litigants impose on time and resources of judges, law clerks, and clerical employees).

32. See, e.g., Osborn v. Manning, 685 P.2d 1121, 1125 (Wyo. 1984) ("Although a litigant should not be punished for self-representation, it is not the function of the court to supervise him in the practice of law.").

33. A pro se litigant receiving legal education should properly inform the court that she has had limited access to some source of legal information. Courts generally want to know the extent to which parties are knowledgeable about the law. Unacknowledged legal assistance may even invoke reprimand from the court. See, e.g., Klein v. H.N. Whitncy, Goadby \& Co., 341 F. Supp. 699, 702 (S.D.N.Y. 1971) (finding that pro se litigant's arguments and papers "strongly suggest that he is enjoying the assistance of a lawyer" and that such practice "should not be countenanced").

While the court and the bar may have an understandable stake in proscribing deception before the court, prohibiting pro se litigants from seeking any legal assistance would be unnecessarily broad. Assistance from counsel not of record should be condemned only if the legal assistance is so extensive that the litigant is not, in fact, appearing pro se. See ABA Comm. on Ethics and Professional Responsibility, Informal Op. 1414 (1978) (pro se litigant received such extensive legal assistance-lawyer "sat in on" trial and advised litigant on "procedural matters" during trial-that lawyer was found to be engaging in misrepresentation).

34. The courts have consistently rejected the right to appointed counsel in civil cases, except under special circumstances. See Lassiter v. Department of Social Servs., 452 U.S. 18 (1981) (rejecting absolute rule requiring appointed counsel in civil cases under due process clause); Aiello v. Commissioner 
most criminal defendants enjoy a constitutional right to counsel, ${ }^{35}$ no parallel right has yet been recognized in civil cases. ${ }^{36}$ Courts have construed due process to require the appointment of counsel in particular types of civil cases, such as mental commitment proceedings ${ }^{37}$ and juvenile delinquency determinations; ${ }^{38}$ but, for the ordinary, indigent civil litigant, as one court put it: "There is a presumption that there is no right to appointed counsel in the absence of at least a potential deprivation of physical liberty." ${ }^{38}$ In passing upon motions for appointment of counsel in civil cases, however, judges enjoy broad discretion in denying counsel. ${ }^{40}$

Although appointed counsel may not be constitutionally required, federal courts ${ }^{41}$ and some state courts ${ }^{42}$ are empowered by statute to appoint counsel for parties appearing in forma pauperis. Some attorneys, however, have successfully challenged the courts' power to compel representation without compensation, even when authorized by statute; ${ }^{\mathbf{4 3}}$ thus, even when courts are inclined to appoint counsel, the court's ability to "ap-

of Pub. Welfare, 358 Mass. 91, 260 N.E.2d 662 (1970) (holding that neither due process nor equal protection clause of Fourteenth Amendment required payment of legal fees); In re Smiley, 36 N.Y.2d 433, 330 N.E.2d 53, 369 N.Y.S.2d 87 (1975) (rejecting claim of constitutional right to counsel in divorce proceeding); In re Brown v. Lavine, 37 N.Y.2d 317, 333 N.E.2d 374, 372 N.Y.S.2d 75 (1975) (holding that due process does not require assignment of counsel in welfare hearing); cf. Kennedy v. Wood, 439 N.E.2d 1367, 1369 (Ind. App. 1982). The court in Kennedy held that an indigent defendant was entitled to counsel in a paternity suit instituted under federal acts and statutes because of potential deprivation of physical liberty. In deciding what due process was required, the court considered the private interests at stake, the government's interest, and the risk that procedures used would lead to an erroneous decision.

35. See Gideon v. Wainwright, 372 U.S. 335 (1963) (constitutional right under due process clause to appointed counsel in criminal cases); see also Argersinger v. Hamlin, 407 U.S. 25 (1972) (same).

36. See supra note 5; see also McAninch, A Constitutional Right to Counsel for Divorce Litigants, 14 J. FAM. L. 509 (1976).

37. See, e.g., Vitek v. Jones, 445 U.S. 480 (1980); F.J. v. State, 411 N.E.2d 372, 377 (Ind. App. 1980).

38. See, e.g., In re Gault, 387 U.S. 1, 4 (1967).

39. Kennedy v. Wood, 439 N.E.2d 1367, 1369 (Ind. App. 1982).

40. See, e.g., United States v. McQuade, 647 F.2d 938, 940 (9th Cir. 1981) (appointment of counsel in civil cases within discretion of trial court and made only in exceptional circumstances), cert. denied, 455 U.S. 958 (1982); Craigo v. Hey, 345 S.E.2d 814 (W. Va. 1986) (appointment of counsel in civil cases within sound discretion of court); Darnell v. Peyton, 208 Va. 675, 160 S.E.2d 749 (1968) (same).

41. See 28 U.S.C. § 1915(d) (1982); see also McKeever v. Israel, 689 F.2d 1315, 1319 (7th Cir. 1982) (affirming court's authority to appoint counsel; rejecting argument that court may not appoint counsel unless authorized to compensate appointed counsel).

42. See, e.g., IND. ConE $\Lambda$ NN. $\$ 34-1-1-3$ (Burns 1972) (court "shall assign [to an indigent] an attorney to defend or prosecute the cause"); MO. ANN. STAT. $\$ 514.040$ (Vernon 1952) (court may assign counsel to poor person); VA. Conf ANN. $\$ 14.1-183$ (1985) (same); W. VA. CoDf $\S 59-2-1$ (1966) (same). But see $\Lambda$ RK. SrAT. $\Lambda$ NN. $\$ \S 27-401$ to -406 (1979) (repealed 1985) (former statute granting court power to appoint counsel for poor person).

43. See, e.g., State ex rel. Scott v. Roper, 688 S.W.2d 757 (Mo. 1985) (en banc). The Missouri Supreme Court held that its state courts may no longer compel uncompensated representation in civil cases, pursuant to Mo. SrA'T. ANN. $\$ 514.040$ (Vernon 1952), since doing so violates attorneys' state constitutional right to "the enjoyment of gains of [person's] own industry." 688 S.W.2d at 769. 
point" counsel may be contingent upon its ability to locate volunteer attorneys or upon statutory authority to compensate appointed counsel.

\section{Legal Services Programs}

Legal services programs are the primary source ${ }^{44}$ of legal assistance for the poor. If fortunate, those individuals eligible for federally-funded legal assistance may receive the assistance of a legal services attorney. ${ }^{45} \mathrm{~A}$ legal services attorney, in most cases, accepts ${ }^{48}$ and handles ${ }^{47}$ legal problems just as a private attorney would; the main difference is that clients do not compensate legal services attorneys for their services. ${ }^{48} \mathrm{But}$, it is clear that legal assistance from legal services programs is a scarce resource, ${ }^{48}$ and dramatic reductions in federal assistance have exacerbated its scarcity. ${ }^{50}$

\section{See supra note 9.}

45. In New Haven, Connecticut, three out of four eligible persons who applied to the New Haven Legal Assistance Association, Inc. for legal assistance could not obtain any legal assistance in 1984 whatsoever, let alone assistance from a legal services attorney. See New Haven Pamphlet, supra note 11.

46. Like private attorneys, legal services programs may limit the scope of services that they offer, and may refuse to offer services. The argument that limitations on services are improper because the indigent have nowhere else to turn for legal services was rejected by the American Bar Association. ABA Comm. on Ethics and Professional Responsibility, Formal Op. 334, at 8-9 (1976) ("legal aid society may broadly limit the categories of legal services its lawyers may undertake for a client"; "limitation upon the scope of services [should be] established prior to the acceptance by the staff lawyer of representation of any particular client").

47. Once a legal services staff attorney accepts a matter, "nothing can be permitted to interfere with that representation to the full extent permitted by law and the disciplinary rules ...." Id. at 9 (referring to Monel. CoDE, supra note 18). The ABA disallowed a legal services program from establishing a system of priorities that resulted in an unmanageable caseload for staff attorneys and an inadequate quality of legal services. $A B A$ Comm. on Professional Ethics and Responsibility, Informal Op. 1359 (1976). Disciplinary Rule 6-101(A) provides that "A lawyer shall not:

(2) Handle a legal matter without preparation adequate in the circumstances.

(3) Neglect a legal matter entrusted to him."

48. Instead of receiving compensation directly from clients, legal services staff attorneys receive salaries-averaging $\$ 21,009$ in 1984-funded by LSC, state and local grants, non-LSC federal grants, and private donations. 1985 Firi.d Program DATA, supra note 8, at 25. In 1985, LSC funded 4,767 attorneys. Id. at 23.

49. As scarce as legal services resources have been in New Haven, Connecticut, see supra note 11, many poverty areas in the country have fared significantly worse. The poverty community served by Legal Services of Central Michigan received only $\$ 4.84$ per person in legal assistance, as compared to $\$ 9.66$ per person for poverty community served by SCGLSC. 1982-1983 Lkgal. Skrvicks CorporaTION ANNUAl. REPORT 17-22. SCCLSC has since merged into New Haven Legal Assistance Association, Inc.

50. Congress appropriated $\$ 305$ million to LSC for the 1981 fiscal year, but reduced appropriations to $\$ 241$ million for the 1982 fiscal year, a reduction of twenty-five percent. $\Lambda$ ppropriations-Fiscal Year 1981, Pub. L. No. 96-536, 94 Stat. 3166 (1980); H.R. 3480, 97th Cong., 1st Sess.; 127 Cong. Rec. H3073, 3117-19 (daily ed. June 18, 1981); H.R. 4169, 97th Cong., 1st Sess.; and 127 Cong. Rec. S13368 (daily ed. Nov. 13, 1981). This funding level was maintained through a series of continuing resolutions through 1983 . In 1984, Congress appropriated $\$ 275$ million to LSC. Continuing Appropriations, 1984, Pub. L. No. 98-107, 97 Stat. 733, 738-40 (1983); Continuing Appropriations, 1984, Pub. L. No. 98-166, 97 Stat. 1071, 1088 (1983). And in 1985, Congress appropriated $\$ 305.5$ million. See Congressional Quarterly 1153 (June 15, 1985). For a discussion of the effect of the 1982 budget cuts on legal services programs, see THE WAStincrion Council. of LAWYers, 
To give proper assistance to clients whose cases are accepted, a legal services program must turn away any excess demand. Some legal services programs have been forced to routinely deny services to ensure quality services for urgent legal problems, and long waiting lists for some types of legal problems are common. ${ }^{\mathbf{5 1}}$

At the same time, other sources of legal services, including pro bono services provided by the private bar, have been unable to fill the gap. ${ }^{52}$ As one commentator has noted:

REPORT ON 'ThE Status of LEGai. SkRvices FOR THE POOR 13-42 (1983) (assessing impact of 25\% reduction in federal funding; some programs reporting reduction of over $50 \%$ of attorney staff); see also Special Project, supra note 9, at $611 \mathrm{n} .186$ (many rural offices forced to close, total staff reduced by $29.8 \%$ ).

Since 1980, the Reagan Administration has been calling for the abolition of the LSC. The Administration's most recent advocate has been W. Clark Durant III, chairman of the LSC, who told the American Bar Association's Board of Governors, "I am calling for the replacement of the Legal Services Corporation. It cannot be reformed . . . Address by W. Clark Durant III, Chairman of the LSC, American Bar Association Board of Governors Winter Meeting (Feb. 12, 1987) (copy on file with author). The American Bar Association has continued to resist the abolition of the LSC and has called for Durant's resignation. See Nat'l L.J., Mar. 2, 1987, at 12, col. 1 (editorial).

Meanwhile, state and local governments have not been forthcoming in supplementing legal services programs. In 1985 , state and local governments contributed only $\$ 20,067,745$, or $6.7 \%$, of the LSC budget. 1985 Fini.D Program Daita, supra note 8, at 14.

51. See, e.g., J. Dooley \& A. Houseman, supra note 9, at 27 of ch. 4; see also S. BRAKEL, JunICiart: 71 (1974) (noting decline in number of domestic cases handled because of policy, established for budgetary reasons, restricting divorce cases). The NHLAA Family Law Unit is often forced to limit its caseload to emergency situations, such as spousal or child abuse and potential child kidnapping cases. Telephone interviews with Robin Murphy, Managing Atorney for Family Law Unit, and Barbara Rey-Deloatch, Paralegal at New Haven Legal Assistance Association (Mar. 3, 1986).

The American Bar $\Lambda$ ssociation has noted:

$\Lambda$ s a practical matter, the resources of a legal services office are always limited and some allocation of them upon a basis of priorities must be made if they are to be effectively utilized. As long as this is done fairly and reasonably with the objective of making maximum legal services available, within the limits of available resources, it is not improper.

ABA Comm. on Ethics and Professional Responsibility, Formal Op. 334, at 9 (1974).

52. See supra note 11. According to an LSC study that tested various methods of delivery as demonstration projects, prepaid legal services plans, legal clinics, and voucher systems were not feasible delivery systems for poor people. See Legal. Serv. Corp., The Delivery Systems Study: A Pol.tcy Reipok't To the Congress and PREsident of THE UnIted STates 8 (1980) [hereinafter Dei.IVERY SYsirm STUDY]. Even when fully operational in communities already served by a regular legal services program, most demonstration projects encountered the same problem of excess demand faced by regular legal services programs, and either had to close intake or reduce their level of new clients to stay within LSC-prescribed budgets. Id. at 11.

Samuel Brakel, project director of the American Bar Foundation's two-year study of judicare, however, concluded that judicare is well designed to reach the poor. S. BRAKEL, supra note 51, at 124-25. Based upon his study of judicare programs in three Wisconsin counties, Brakel concluded that judicare is superior to the staff-office model in several areas: in ability to reach the poor, in offering the client a choice of lawyers, and in quality of service. Id. at 123-29.

Prepaid legal services plans and legal clinics have been successful only when geared to middleincome people. See Lewin, Legal Advice: $\$ 6.75$ a Month, N.Y. Times, Feb. 3, 1987, at D1, col. 3 ("different concerns, including . . . legal clinics, are scrambling to carve out a piece of . . that market [of middle-income $\Lambda$ mericans]"). These services cannot remain financially solvent when the clientele consists primarily of low-income people. See D. Maron, Legal Clinics: Analysis and Surviry 15-23 (2d ed. 1977). Nor has the private bar filled the gap. See Washington Council. OF LAWYE.R, supra note 50, at 43-48; see also J. Dooley \& $A$. Houseman, supra note 9, at 26-27 of ch. 4; Arriola \& Wolinsky, supra note 11 , at 1218 . 
$[\mathrm{P}]$ ro bono services satisfy at present . . . only a small and haphazardly selected portion of the legal needs of the poor. Indeed, it was the inadequacy of private legal aid programs and pro bono activities by individual attorneys that led to the establishment of federally funded legal services in the first place. $^{\mathrm{s3}}$

In addition, various theories on maximizing the existing resources of legal services programs have made little headway in reaching individual members of the low-income community. Some scholars have advocated the use of impact litigation ${ }^{54}$ or class action suits; ${ }^{.55}$ in practical terms, however, group litigation is not designed to address specific problems of individuals. ${ }^{86}$ Another proposal to increase the availability of legal assistance is the use of lay representatives ${ }^{57}$-presumably a less expensive resource than attorneys. The use of lay representatives, such as trained paralegals and social workers, could increase the dissemination of legal information. Not surprisingly, this proposal has encountered staunch opposition from the bar and has been rejected by at least one state court. ${ }^{68}$

\section{Publications and Self-Help Materials}

Currently, many states allow a pro se litigant to obtain general legal information from written publications. ${ }^{58}$ But publications obviously can-

53. Special Project, supra note 9, at 638 (footnotes omitted).

54. Impact litigation refers to work that aims to achieve "long-lasting improvement, or avoidance of deterioration, in the living conditions of significant segments of the eligible population." DrL.rvERY Systrms Srudy, supra note 52, at 31. Critics charge that the resources necessary to prepare and litigate "impact" cases would be better spent on smaller, nonpolitical matters. For a description of this debate, see B. GaRTH, NeIchborhoon Law FIRMS For THE. POOR 172-78 (1980); see also Brakel, Legal Services for the Poor in the Reagan Years, 68 A.B.A. J. 820, 821 (1982) (objecting to emphasis on "group representation and so-called impact litigation at the expense of individual service requests"); Breger, Legal Aid for the Poor: A Conceptual Analysis, 60 N.C.L. Rev. 282 (1982) (same).

55. See generally Failinger \& May, Litigating Against Poverty: Legal Services and Group Representation, 45 OHiO Sr. L.J. 2 (1984) (discussing maximization of legal services for poor through class action suits); Special Project, supra note 9, at 633-34 (discussing need for group advocacy).

56. See Breger, supra note 54. Breger attacks proponents of class action and impact litigation, and instead, advocates a theory of "access rights" under which a person should be entitled to free legal aid regardless of the moral or social utility of their particular claim. Id. at 297-336. Breger argues that since the needs and desires of each individual are equally worthy of respect, legal aid organizations should not select recipients of assistance based upon a judgment of moral or social worth. Impact litigation, he argues, is not justifiable because it is inherently selective. Id. at 295-97.

57. Advacates of lay presentation have focused on no-fault, uncontested divorces and simple transactions, such as wills and deeds. See Rhode, Policing the Professional Monopoly: A Constitutional and Empirical Analysis of Unauthorized Practice Prohititions, 34 SrAN. L. Rrv. 1 (1981); Hicks \& Katz, The Practice of Law by Laymen and Lay Agencies, 41 YAl.F. L.J. 69 (1931); Note, supra note 29.

58. See Thomas, The Hidden Agency of the Radical Right, N.Y. Times, Mar. 15, 1987, § 3, at 2, col. 3. The author, Eugene C. Thomas, is president of the American Bar Association.

59. Some states, including New York, Michigan, Missouri, New Jersey and Oregon, have exempted written publications and "do it yourselp" kits providing general legal information and blank legal forms from rules against unauthorized practice of law. See, e.g., New York County Lawyers' Ass'n v. Dacey, 21 N.Y.2d 694, 234 N.E.2d 459, 287 N.Y.S.2d 422 (1967); State v. Winder, 42 
not be as effective as instruction that is narrowly targeted to the person's particular problems. Even assuming self-help manuals are accurate, wellwritten, and easy to comprehend, they do not afford the pro se litigant the opportunity to ask questions or clarify the material. To proceed effectively, a pro se litigant needs direct access to general information pertinent to her legal problem.

\section{Legal Education for the Pro Se Litigant}

For some pro se litigants, legal education may constitute the sole source of information to which they have access, given the scarcity of free legal services and the limited circumstances in which court-appointed counsel can be expected. Whether she proceeds pro se by choice or necessity, the pro se litigant must obtain information that both clarifies the legal bases of her claims and explains the relevant procedural rules to be able to make an effective presentation before the court. A better-educated pro se litigant may still fare better if she were represented by counsel, but the alternative-leaving the litigant in total ignorance-is clearly much worse, for both the litigant and the court. Access to such information may even encourage those who would otherwise forego an opportunity to present their claims in court to exercise their right to be heard.

Legal education in a classroom setting will not be appropriate for all legal problems, and its usefulness will depend on the needs of the community. Whether a legal problem is suitable for classroom instruction will

A.D.2d 1039, 348 N.Y.S.2d 270 (1973); State Bar v. Cramer, 399 Mich. 116, 249 N.W.2d 1 (1976); Oregon State Bar v. Gilchrist, 538 P.2d 913 (Or. 1976); Sup. Ct. Comm'n on the Unauth. Prac. of Law, Op. 20, 100 N.J.L.J. 893 (1977).

Indeed, preventing laypersons from publishing nonpersonalized legal information or advice appears to violate the First Amendment. $C$. Lowe v. SEC, 105 S. Ct. 2557, 2574 (1985) (White, J., concurring). Although Lowe addressed the regulation of publishers of nonpersonalized investment advice, Justice White's analysis of the permissibility of restraining speech applies equally well to the provision of nonpersonalized legal advice. According to Justice White, legislation that restrains speech is permissible where it is a legitimate exercise of the power to regulate a profession; however, where the speech falls outside the scope of a regulated profession, restraints on that speech would violate the First Amendment. Justice White defines one who is "properly viewed as engaging in the practice of a profession" as one who "takes the affairs of a client personally in hand and purports to exercise judgment on behalf of the client in the light of the client's individual needs and circumstances." $105 \mathrm{~S}$. Ct. at 2584 . Thus, the publication of legal forms and general instructions should be permitted in all states.

Yet, a few states bar the publication of legal forms and instructions. See Florida Bar v. Stupica, 300 So. 2d 683 (Fla. 1974) (rejecting argument that mere sale of legal forms and instructions was legal because of lack of personal lawyer-client relationship; unauthorized practice begins when legal forms are accompanied by instructions); $\Lambda$ laska Bar $\Lambda$ ss'n v. Foster, C.A. No. 73-161 (Alaska Oct. 29, 1973), reprinted in 39 Unauth. Prac. News 75, 75-80 (1974) (injunction against kit sale, form preparation, and advice); Minnesota State Bar $\Lambda$ ss'n v. Divorce Reform, Inc., No. 396447 (Ramsey County Dist. C. Minn. Apr. 18, 1975), reprinted in 39 Unauth. Prac. News 187, 188-93 (1975) (enjoining sales of forms, form preparation services, and advice); State Bar v. Brandon (Clark County Dist. Ct. Nev. Aug. 16, 1972), reprinted in 37 Unauth. Prac. News 32, 37-42 (1973) (enjoining provision of kits and advice, and preparation of pleadings). 
depend upon the extent to which legal solutions are standardizable,$^{60}$ and the extent to which the problem involves questions of fact whose resolution is not too difficult to ascertain. Legal claims for which the applicable law is unambiguous and easily comprehended, and for which obtaining the necessary factual material does not require discovery or other complex fact-finding mechanisms, may be suitable for classroom instruction. Conversely, where the law is controversial, ambiguous, or has not been clearly interpreted by the courts, classroom instruction would be inappropriate.

\section{A. A Model Class on Summary Evictions}

Although landlord-tenant law is a complex body of law, the scope of knowledge necessary to render effective legal assistance in many cases can be narrowly circumscribed. Case law on the timing of notice provisions, the valid delivery of notice, and common defenses to evictions, such as habitability, tender of rent, retaliatory eviction, and waiver, may be wellestablished. In addition, the facts necessary to establish whether notice was properly given, whether housing conditions violate warrants of habitability, ${ }^{61}$ or whether rent has been accepted by the landlord are not difficult to ascertain.

Presenting an example of a legal education class addressing summary eviction proceedings may clarify how such a class would operate. ${ }^{62}$ The attorney/instructor would inform the class-laypersons who have received eviction notices-of the scope of the material that she intends to cover, namely, the appearance, the answer, common defenses, trial preparation, and negotiation. The attorney/instructor would distribute copies of an appearance, a reply, and pamphlets describing the summary eviction process. She would begin by explaining the importance of filing an appearance, as well as the consequences of not filing an appearance-default. She would explain the filing procedure, where the court is, the court's assignment of cases, and how long the pro se litigant can expect to wait before going to trial.

Turning next to defenses, the attorney/instructor would describe each of the common defenses: habitability, tender, waiver, and retaliatory eviction. For habitability, she would inform the class that every person has a

60. The bulk of a legal services lawyer's work involves handling routine legal problems for individuals. See Special Project, supra note 9, at 618. Legal services programs commonly maintain standardized legal documents for routine problems.

61. In most cases, a tenant can easily identify the means by which she received natice from a landlord-by mail, in person, or stuffed under the door. Similarly, determining the existence of housing violations may be obtained by requesting local housing authorities to evaluate the premises.

62. The instruction need not occur in a single session. The attorney/instructor may find it more beneficial to divide the material into two sessions: one for the appearance, answer, and common defenses; the other for trial preparation and negotiation. 
right to a "fit and habitable" dwelling. She would describe conditions that are unquestionably in violation of the warrant of habitability, such as the lack of smoke detectors or the presence of lead paint. She would inform the class that they can request an inspection from the local housing authority if they believe they have a habitability defense. She would similarly describe other defenses and the facts that are necessary to assert those defenses.

The attorney/instructor would then discuss how to prepare for trial. She might construct a replica of the local courthouse, to lessen the impact of unfamiliarity or intimidation that a courtroom may evoke. She would describe what a litigant may bring as evidence of her defenses, such as a cancelled check in a tender defense, a copy of the housing authority report in a habitability case, or photographs of alleged habitability violations.

In describing the possibilities of negotiation, the attorney/instructor's goal would be to assist the tenant in negotiating an agreement that the tenant can reasonably expect to keep. She would explain that it may be in the interests of both the landlord and the tenant to negotiate an understanding, rather than to have both parties litigate the matter. If the municipality provides for housing specialists, who assist parties in negotiating their differences, she would explain the process involved in obtaining the housing specialist's assistance. She would describe the interests that the landlord has in avoiding trial or execution of the eviction, such as sheriff's fees and possible attorney's fees. She would then assist the class in identifying their individual objectives: whether a participant wishes to stay in her dwelling or needs time to find another dwelling; the minimum and maximum amount of time she may need to find another dwelling; whether she has the money to pay the costs of moving; whether she has the financial means to negotiate a longer period of time through payment of use and occupancy. The attorney/instructor would also discuss the consequences of losing the case at trial, and the fact that in a nonpayment case, the tenant may have as little as five days after judgment at trial before execution of the eviction, as compared to other grounds for summary eviction that would allow for longer periods of time before execution.

\section{B. Addressing Participant's Questions}

A class participant should be permitted to clarify her understanding of the material presented. For the pro se litigant, the opportunity to ask questions may constitute the greatest advantage of classroom education over published, self-help materials. If a participant offers facts particular to her situation, the attorney/instructor may wish to qualify her response 
to apply only to the facts offered. ${ }^{63}$ Since paralegals may not provide factspecific advice in light of unauthorized practice of law regulations, ${ }^{64}$ paralegals conducting classes may either refuse to respond or choose to explain the law in only general terms. Alternatively, legal services programs could provide attorneys at the end of class to answer fact-specific questions.

\section{The Ethical Propriety of Legal Education}

Both the Model Rules of Professional Conduct and the Model Code of Professional Responsibility set standards of professional conduct for lawyers in those jurisdictions that have adopted them. ${ }^{65}$ Violations of duties imposed by either set of standards may result in disciplinary sanctions, ${ }^{6 B}$ and may also be used as evidence of malpractice. ${ }^{67}$ For this reason, whether the proposed classroom instruction is consistent with the Model Rules and Model Code is an important issue.

\section{A. Legal Education as a Public Service}

The American Bar Association has long approved of efforts by lawyers to provide the public with information on legal problems of general inter-

63. For a discussion of the attorney/instructor's ethical duties, see infra Section III.

64. For a compilation of state unauthorized practice laws, see J. Fischer \& D. LAchmanN, UNAUTHORIZFi PRAC:IICE: HaNDBOOK 6-110 (1972).

65. As of February 18, 1987, twenty states had adopted the Model Rules, supra note 19: Arizona, Arkansas, Connecticut, Delaware, Florida, Idaho, Indiana, Louisiana, Maryland, Minnesota, Mississippi, Missouri, Montana, Nevada, New Hampshire, New Jersey, New Mexico, North Carolina, Washington and Wyoming. Letter from Nancy Katz, $\Lambda$ ssistant Counsel, American Bar $\Lambda$ ssociation, to author (Mar. 2, 1987) [hereinafter Katz Letter]. As of September 24, 1985, one state, Virginia, had officially rejected the Model Rules, and study committees in five other states-Illinois, Ohio, Oregon, Tennessee, and Vermont-had recommended retention of the Model Code. See Rosiny, Debating the Model Rules-Critical Points of Contention, N.Y.L.J., Sept. 24, 1985, at 1, col. 3.

The Monk1. Cons, supra note 18, is currently in effect, with minor variations, in the District of Columbia, the Virgin Islands, and twenty-seven states: Alaska, California, Colorado, Georgia, Hawaii, Illinois, Iowa, Kansas, Kentucky, Massachusetts, Michigan, Nebraska, New York, Ohio, Oklahoma, Oregon, Pennsylvania, Rhode Island, South Carolina, South Dakota, Tennessee, Texas, Utah, Vermont, Virginia, West Virginia, and Wisconsin. Katz Letter, supra.

66. See Monel. Rut.s, supra note 19, Scope ("Some of the Rules are imperatives . . . These define proper conduct for purposes of professional discipline."); Monr. Conk, supra note 18, Preliminary Statement (anticipating use of Monk. Conk as interpretive guide by enforcing agency).

67. See, e.g., Woodruff v. Tomlin, 616 F.2d 924, 936 (6th Gir. 1980) (en banc) (relying on Code to interpret standard of attorney's negligence), cert. denied, 449 U.S. 888 (1980); Lipton v. Boesky, 110 Mich. App. 589, 598, 313 N.W.2d 163, 167 (1980) (violation of Code is rebuttable evidence of malpractice). Most judges and scholars, however, do not favor imposition of civil liability based upon violation of the Model Code. See, e.g., Bob Godfrey Pontiac v. Roloff, 291 Or. 318, 330-31, 630 P.2d 840,846 (1981) and cases cited therein; Birnbaum, Physicians Counterattack: Liability of Lauyers for Instituting Unjustified Medical Malpractice Actions, 45 FornhaM L. Rrv. 1003, 1074-77 (1977); Thode, The Groundless Case-The Lawyer's Tort Duty to His Client and to the Adverse Party, 11 ST. Mary's L.J. 59, 73-74 (1979). Contra Comment, The Georgia Code of Professional Responsibility: A Catalyst for Successful Legal Malpractice Actions?, 37 MrRckr L. Rkv. 817 (1986). 
est. It has consistently recognized the importance of educating the public, and has approved dissemination of legal information through several different mediums: television programs, ${ }^{68}$ radio programs, ${ }^{69}$ seminars, ${ }^{70}$ and newspaper columns. ${ }^{71}$

The American Bar Association's position is reflected in the Model Code's position on legal education. ${ }^{72}$ The Model Code encourages ${ }^{73}$ lawyers to assist laypersons "to recognize legal problems," urges lawyers to "participate in educational and public relations programs concerning our legal system with particular reference to legal problems that frequently arise."'rs

The proposed classroom instruction is clearly consistent with these aspirational duties since it would provide information on legal topics of gen-

68. ABA Comm. on Professional Ethics, Informal Op. 1179 (1971) (approving series of half-hour television presentations on uses of life insurance in estate planning); $\Lambda \mathrm{B} \Lambda$ Comm. on Professional Ethics, Informal Decision C-230(g) (1961) (lawyer's appearance on public service program, "Meet the Press," proper); $c f . \Lambda B \Lambda$ Comm. on Professional Ethics, Formal Op. 298 (1961) (lawyer's appearance on public information television program is consistent with $A B \Lambda$ Canons of Professional Ethics, but simulation of judicial proceedings is not).

69. $\triangle B A$ Comm. of Professional Ethics, Informal Op. 1136 (1969); ABA Comm. of Professional Ethics, Informal Op. 1094 (1969) (radio program discussing court decisions, agency rulings, and giving lawyer's personal analysis of decision is ethical).

70. $\Lambda \mathrm{B} \Lambda$ Comm. on Professional Ethics, Informal Op. 840 (1965) (interpreting prior, official ABA Canons of Professional Ethics).

71. $\Lambda \mathrm{B} \Lambda$ Standing Comm. on Ethics and Professional Responsibility, Informal Op. 85-1510 (1985) (under both Model Rules and Model Code, lawyers may author articles providing general legal information for use in publications prepared for distribution to nonlawyers); $\triangle B A$ Comm. on Professional Ethics, Informal Op. 1198 (1971) (lawyer who writes for newspapers and magazines for géneral public may identify herself as author under Monk. Conf, supra note 18, EC 2-2, 2-5, DR

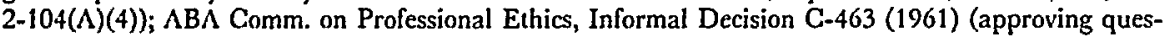
tion and answer column confined to general treatment of legal subjects).

72. In contrast to the Model Code, the Model Rules do not specifically address the provision of legal information to the public. However, they do express a more general policy of rendering public interest legal service. Rule 6.1 urges lawyers to provide services at no fee or reduced fees; to participate in activities for improving the law, the legal system, or the legal profession; and to extend financial support to organizations that provide legal services to persons of limited means. MODEI. RUI.Es, supra note 19, Rule 6.1. However, Rule 6.1 is not mandatory; thus, it is unlikely that it will have much impact, if any, on whether the private bar will address the demand for legal services that legal services programs cannot meet. See supra notes 52-53 and accompanying text.

In determining whether a legal information column published in a corporate newsletter was permissible, the $\Lambda$ merican Bar Association noted that the Model Rules do not prohibit lawyers from authoring articles providing general legal information. $\Lambda \mathrm{B} \Lambda$ Standing Comm. on Ethics and Professional Responsibility, Informal Op. 85-1510, at 2 (1985).

73. Conduct inconsistent with an Ethical Consideration deserves attention to the extent that scholars and members of the profession regard Ethical Considerations as creating ethical duties. See Finman \& Schneyer, The Role of Bar Association Ethics Opinions in Regulating Lawyer Conduct: A Critique of the Work of the ABA Committee on Ethics and Professional Responsibility, 29 UCLA L. Rkv. 67, 74 (1981). Unlike Disciplinary Rules, Ethical Considerations are aspirational, not mandatory; however, they "represent the objectives toward which every member of the profession should strive." Mobri. Cont, supra note 18, Preliminary Statement. $\Lambda$ s one commentator has noted, Ethical Considerations "have elevated the practice and provided considerable guidance to ethically sensitive lawyers-lawyers who, like most of us, want to do what is right." Rosiny, Debating the Model Rules-Critical Points of Contention, N.Y.L.J., Sept. 23, 1985, at 1, col. 3.

74. Monki. Conk, supra note $18, \mathrm{EC} 2-2$

75. Id. EC $2-5$. 
eral public interest. ${ }^{76}$ In fact, as compared to television and radio programs and newspaper columns, classroom instruction is a superior educational vehicle, for it provides the additional opportunity of clarifying one's understanding of the material with the aid of the attorney/ instructor.

The proposed classes do depart, however, from "pure" education. Unlike television, radio, and newspapers, which are aimed at the general public, the classes would be aimed more narrowly at members of the public who are interested in applying the material to their individual situations. While it may be true that information provided through television, radio, and newspapers also attracts the attention only of interested members of the public, the Model Code specifically discourages the use of publicly-provided information:

A lawyer who writes or speaks for the purpose of educating members of the public to recognize their legal problems should carefully refrain from giving or appearing to give a general solution applicable to all apparently similar individual problems, since slight changes in fact situations may require a material variance in the applicable advice; otherwise the public may be mislead [sic] and misadvised. Talks and writings by lawyers for laypersons should caution them not to attempt to solve individual problems upon the basis of the information contained therein. ${ }^{27}$

The admonition against acting upon the information provided makes sense for those who have the capacity to hire counsel, but it ignores reality for those who do not. The indigent, by definition, lack the capacity to hire counsel. Advising the public not to rely on accurate legal information only furthers the public's dependency upon the legal profession. While such dependency might not be offensive if those unable to hire counsel could be assured of obtaining counsel, the fact that the bar has not filled the gap left by legal services programs renders the admonition against using publicly-provided information particularly obnoxious.

Furthermore, the Model Code's approach to educating the public is too narrow. The Model Code's approach, in effect, discourages attorneys from

76. Significantly, classroom instruction does not fall within the ambit of the "minimal service" approach that was expressly rejected by the American Bar $\Lambda$ ssociation. ABA Committee on Professional Ethics and Grievances, Informal Op. 1359, at 1 (1976). The Committee, while expressing sympathy for public interest attorneys operating under the constraints of limited resources, expressly rejected the argument that "fairness and reason are best served by giving all indigents some although perhaps inadequate legal advice" as inconsistent with the duty to represent a client competently. However, the classroom instruction proposed here is informational; it does not trigger an attorneyclient relationship. In other words, classroom instruction cannot constitute "minimal service" precisely because no legal "representation" is taking place.

77. Monei. Cons, supra note 18, EC 2-5 (footnotes omitted) (emphasis added). 
making information available that indigent pro se litigants cannot otherwise receive, ${ }^{78}$ and creates an all-or-nothing approach to the provision of legal services: A layperson must either hire an attorney or proceed pro se in virtual ignorance. Legal education should not stop at the point when it educates the public to recognize a legal problem or to recognize the need for an attorney's services. It overlooks the possibility that information given in a public forum, when properly designed and limited to particular areas of substantive or procedural law, can be accurate and valuable to those who proceed pro se. Given the scarcity of legal services and the potential value of providing legal information in a public forum, for both the courts and the pro se litigant, classroom instruction should be viewed as consistent with the ethical consideration that encourages lawyers to support and participate in activities that aim to achieve equality before the law. ${ }^{78}$

\section{B. Legal Education as Practice of Law}

Even if the proposed classroom education were not considered purely educational, but were interpreted to constitute the practice of law, it should nonetheless be considered permissible, since both the Model Code and the Model Rules allow an attorney and client to limit the scope of the attorney's assistance to the client.

First, however, the Model Rules do not define when an attorney-client relationship exists. ${ }^{80}$ The question presumably is determined by state law. In looking at judicial determinations of whether an attorney-client relationship exists, it is apparent that whether the relationship exists turns upon the nature of the duty which the "client" seeks to impose upon the lawyer. In most states, the attorney-client relationship is fundamentally a

78. The Model Code recognizes that "[t]hose persons unable to pay for services should be provided needed services," Monki. Conk, supra note 18, EC 8-3, but it does not address how that need can actually be met. In fact, by assuming that all laypersons will have access to an attorney, the Model Code takes a rather unrealistic approach to the problems facing the pro se litigant:

The prohibition against a non-lawyer practicing law does not prevent a layman from representing himself, for then he is ordinarily exposing only himself to possible injury. . . . [T] legal profession should help members of the public to . . . understand why it may be unwise for them to act for themselves in matters having legal consequences.

Monet. Conf, supra note 18, EC 3-7.

79. See Mone!. Cone, supra note 18, EC 2-16.

80. Monki. Rui.Fs, supra note 19 , Scope ("[F]or purposes of determining the lawyer's authority and responsibility, principles of substantive law external to these Rules determine whether a clientlawyer relationship exists."). 
contractual one, ${ }^{81}$ the existence of which depends upon the actual intentions of the parties and the specific circumstances. ${ }^{82}$

The Model Rules permit a lawyer to limit the scope and objectives of legal assistance, provided the client consents. ${ }^{83}$ As long as the attorney informs the client that she is free to seek other counsel on a different basis, ${ }^{84}$ the attorney has no obligation to offer the legal assistance the client seeks. ${ }^{85}$ Thus, the attorney/instructor should initially inform prospective class participants that, although she is willing to provide them with legal information, she does not intend to represent them as their attorney and that the scope of the instruction is limited to issues actually discussed. The attorney/instructor should probably obtain written acknowledgement from each class participant before the classes begin. ${ }^{86}$

If the class participant is a client, according to Professors Hazard and Hodes, "then all the professional duties that run in favor of clients attach with full force." 87 "The [attorney-instructor's] professional responsiblities to class participants depend primarily on whether the class participants are clients or not." ${ }^{\prime 88}$ The nature of an attorney's duties corresponds to the scope of the representation: The attorney/instructor should not expect to fulfill the duties that are normally imposed on the attorney in the traditional attorney-client relationship, provided the attorney/instructor is careful to make clear the limited scope of her assistance.

81. Id. But see Tormo v. Yormark, 398 F. Supp. 1159, 1169 (D. N.J. 1975) ("law of New Jersey imposes duties incident to such relationship on one who merely "assumes to give legal advice and counsel.' . . . Neither contractual formality nor compensation or expectation of compensation is required" (citation omitted)).

82. See, e.g., Westinghouse Elec. Corp. v. Kerr-McGee Corp., 580 F.2d 1311 (7th Cir. 1978), cert. denied, 439 U.S. 955; Kane, Kane \& Kritzer, Inc. v. Altagen, 107 Cal. App. 3d 36, 165 Cal. Rptr. 534 (1980); Miller v. Metzinger, 91 Cal. App. 3d 31, 154 Cal. Rptr. 154 (1979); cf. R. MALI.eN \& V. Levir, Ligial. Mal.PRactric: $\S \S 101,123$ (1981).

83. " $\Lambda$ lawyer may limit the objectives of the representation if the client consents after consultation." Monri. Rul.ks, supra note 19, Rule 1.2(c).

84. See G. Hazard \& W. Hodfs, The law of Lawyering: $A$ Handbook on the Model. Rul.ks of Profrssional. Coniducir 28 (1985). According to one of the case examples, neither the lawyer's "take it or leave it" proposition, nor the fact that the client may not be able to obtain counsel willing to take her case on a different basis, makes the lawyer's conduct improper. Id. (Illustrative Case (e)).

85. Id.

86. If she does not inform class participants that she is neither representing them, nor extending the scope of her legal services beyond information, the attorney/instructor may unwittingly create a relationship based upon a broader scope of services than she intended. If there is any doubt whether an attorney-client relationship exists, and the attorney/instructor fails to protect the interests of the class participants, she may be subject to malpractice liability. Id. at 49.

87. G. HAZARD \& W. Honfs, supra note 84 , at 53 . The principle professional duties prescribed in the Model Rules include the duty to maintain confidences (Rule 1.6), to avoid conflicts of interest (Rule 1.7), and to act competently and diligently (Rules 1.1 and 1.3), as well as other duties including the duty to communicate (Rule 1.4) and the duty of fair dealing (Rule 1.8(a)). Id.

88. Id.; $c f$. R. MAl.t.t. \& V. Lkvrr, supra note 82, 1101 (circumstances creating attorney-client relationship determine existence and extent of duty that attorney owes to client). 


\section{Standards Governing the Attorney: A Tort Theory of LIABILITY}

Since neither the Model Code of Professional Responsibility nor the Model Rules of Professional Conduct envision the layperson's use of information publicly provided by attorneys, neither provides standards appropriate to govern the conduct of the attorney/instructor. This Note proposes that tort standards be applied to provide an incentive for attorneys to exercise their professional responsibilities with prudence and care. ${ }^{88} \mathrm{In}$ Togstad v. Vesely, Otto, Miller $\mathcal{E}^{\circ}$ Keefe, ${ }^{90}$ the Minnesota Supreme Court applied general principles of tort in finding that an attorney-client relationship had been created. Togstad illustrates the reasonable expectations of laypersons who receive information from an attorney and establishes an appropriate tort standard to govern attorney conduct. A prospective client, Togstad, had not yet retained the defendant law firm, but had approached one of its attorneys for an initial consultation as to a possible malpractice cause of action against her husband's attending physician. The attorney advised Togstad that the facts were insufficient to support a medical malpractice suit. Ten months later, after the two-year statute of limitations had expired, Togstad learned that there was a strong likelihood that the attorney's advice had been erroneous. Although it was clear that Togstad had never formally retained the law firm, the court nonetheless found that an attorney-client relationship, sufficient to support a malpractice action, had been created. The test which the court applied was whether the proposed client "received legal advice . . . under circumstances which made it reasonably foreseeable [to the attorney] that [the client] would be injured if the advice were negligently given." ${ }^{\text {191 }}$

Clearly, the attorney's duty to exercise reasonable care in giving professional advice arose from the attorney's position as an expert on legal matters, and not from a contractual attorney-client relationship. ${ }^{92}$ Using this tort approach, this Note proposes that two duties apply to attorneys who provide legal information to pro se litigants: 1) the duty to render information accurately and 2) the duty not to create an attorney-client relationship.

89. Malpractice actions usually require the establishment of a contractual attorney-client relationship, regardless of whether the suit is in contract or in tort. See Note, Attorney Malpractice: Use of Contract Analysis to Determine the Existence of an Attorney-Client Relationship, 63 MINN. L. REv. 751,752 (1979). Since this Note's proposal of classroom education for pro se litigants is premised on the provision of general, non-personalized information and should not even constitute the practice of law, see supra note 59 , a class participant should be unable to establish a malpractice claim for lack of a contractual attorney-client relationship.

90. 291 N.W.2d 686 (Minn. 1980).

91. Id. at 693 .

92. See Note, supra note 89 , at 758 . 


\section{A. The Duty To Render Information Accurately}

Like the attorney in Togstad, the attorney/instructor should have a duty to render information accurately. Thus, an attorney should be liable for information negligently rendered. In conducting a class for pro se litigants, the attorney is well aware that the people seeking legal information and advice are likely to rely, and act, upon the information provided. In this sense, the attorney/instructor's position is no different from that of an attorney in the traditional attorney-client relationship.

\section{B. The Duty Not To Create an Attorney-Client Relationship}

Unlike the attorney in a traditional attorney-client relationship, the attorney/instructor does not anticipate personal responsibility for applying legal information to the facts of each pro se litigant's situation. Upon the commencement of each class, the attorney/instructor must clearly and carefully define the scope of her functions. She should advise participants that the classes provide a source of information only, and that the attorney/instructor will not take any actions on a participant's behalf. The attorney/instructor should advise class members that they bear the responsibilities for filing legal documents and appearing in court.

Absent evidence to the contrary, the classes should be given a presumption of no attorney-client relationship. If, however, the attorney/instructor should create an expectation that she is accepting an attending layperson as a "client," the attorney should bear the responsibility of falsely creating any expectation of a traditional attorney-client relationship. Failure to meet this responsibility should result in the imposition of duties flowing from the traditional attorney-client relationship.

\section{CoNCLUSION}

Many indigent civil litigants today are unable to obtain the services of an attorney. In the absence of attorney representation, indigent litigants should be afforded at least the opportunity to present effectively their legal claims pro se. The dissemination of legal information to groups of individuals cannot give pro se litigants the same level of expertise that attorneys may possess; however, to the extent that it increases a pro se litigant's knowledge of her legal position, increases the possibility of an effective presentation of her position before the court, and decreases her dependence upon discretionary assistance from a judge, such legal education should be encouraged. Classroom instruction can be a valuable tool in providing crucial legal information to litigants without counsel. 